\title{
Editorial
}

\section{Early life processes: A geo- and astrobiological approach}

\author{
Jan-Peter Duda ${ }^{1,2}$ and Joachim Reitner ${ }^{1,2}$ \\ ${ }^{1}$ Department of Geobiology, Geoscience Centre, Georg-August-University Göttingen, Goldschmidtstr. 3, 37077 Göttingen, \\ Germany e-mail: jan-peter.duda@geo.uni-goettingen.de; jreitne@gwdg.de \\ ${ }^{2}$ Origin of Life Group, Göttingen Academy of Sciences and Humanities, Theaterstr. 7, 37073 Göttingen, Germany
}

\section{Introduction}

The search for potential extraterrestrial life has been a hot topic for a long time. In almost the same manner, the origin and early diversification of life on Earth has been of great interest for many people in and outside academia for decades. Fundamental problems related to both issues, as for instance the identification of potential biosignatures and habitable environments, are strikingly similar. This scientific and technological overlap gave rise to the field of astrobiology (e.g. Dick \& Strick 2004; Farmer 2011).

Most aspects of astrobiology are inherently linked to the field of geobiology (e.g. Reitner \& Thiel 2011; Knoll et al. 2012). Examples include the search for biosignatures, the reconstruction of early life processes from the rock record and the investigation of recent analogues for past environments. One of the few differences is that astrobiology also includes the investigation of extraterrestrial materials. In either case, however, research projects are commonly rather discipline- than problem-specific, and all scientific approaches have their technical and interpretative limitations.

Aiming at stimulating discussion across different scientific disciplines, the international symposium 'Dating the origin of Life: Present-Day Molecules and First Fossil Record' was held at the Göttingen Academy of Sciences \& Humanities (GASH) in October 2014. This symposium was financed by the Deutsche Forschungsgemeinschaft (RE 665/39-1), the GASH, and the Courant Research Centre of Geobiology (Reitner et al. 2014; Fig. 1). This special issue of the International Journal of Astrobiology attempts to reflect the scientific spirit of this meeting.

\section{Biosignatures and reconstruction of early life processes from the rock record}

Lipid biomarkers are powerful tools for the identification of life (e.g., Treibs 1934a, b; 1936; Eglinton \& Calvin 1967; Brocks \& Summons 2003), but are commonly biased by secondary processes such as thermal maturation. Mißbach et al. (this issue) experimentally assessed the thermal stability of selected kerogen-bound lipid biomarkers. Their study revealed major differences, sounding a note of caution for the interpretation of lipid biomarkers in rocks that experienced higher temperatures.

Stable sulfur isotopes $\left({ }^{32} \mathrm{~S},{ }^{33} \mathrm{~S},{ }^{34} \mathrm{~S}\right.$ and $\left.{ }^{36} \mathrm{~S}\right)$ are influenced by microbial sulphur processing (e.g. Strauss 1997; Hoefs 2015). Montinaro \& Strauss (this issue) review the current knowledge about the Archean sulfur cycle, and discuss the impact of microbial driven sulphur cycling. They demonstrate the meaning and potential of sulphur isotope analyses for understanding sulphur cycling on the early Earth, including the reconstruction of sources and (microbial) fractionation pathways.

Since their first occurrence, cyanobacteria have fundamentally shaped the bio- and geosphere by producing molecular oxygen as a metabolic by-product (e.g. Blankenship \& Hartman 1998; Blankenship 2010; Lyons et al. 2014). Schirrmeister et al. (this issue) summarize the current knowledge about cyanobacterial evolution during the Precambrian, including their phylogenetic history, their fossil 

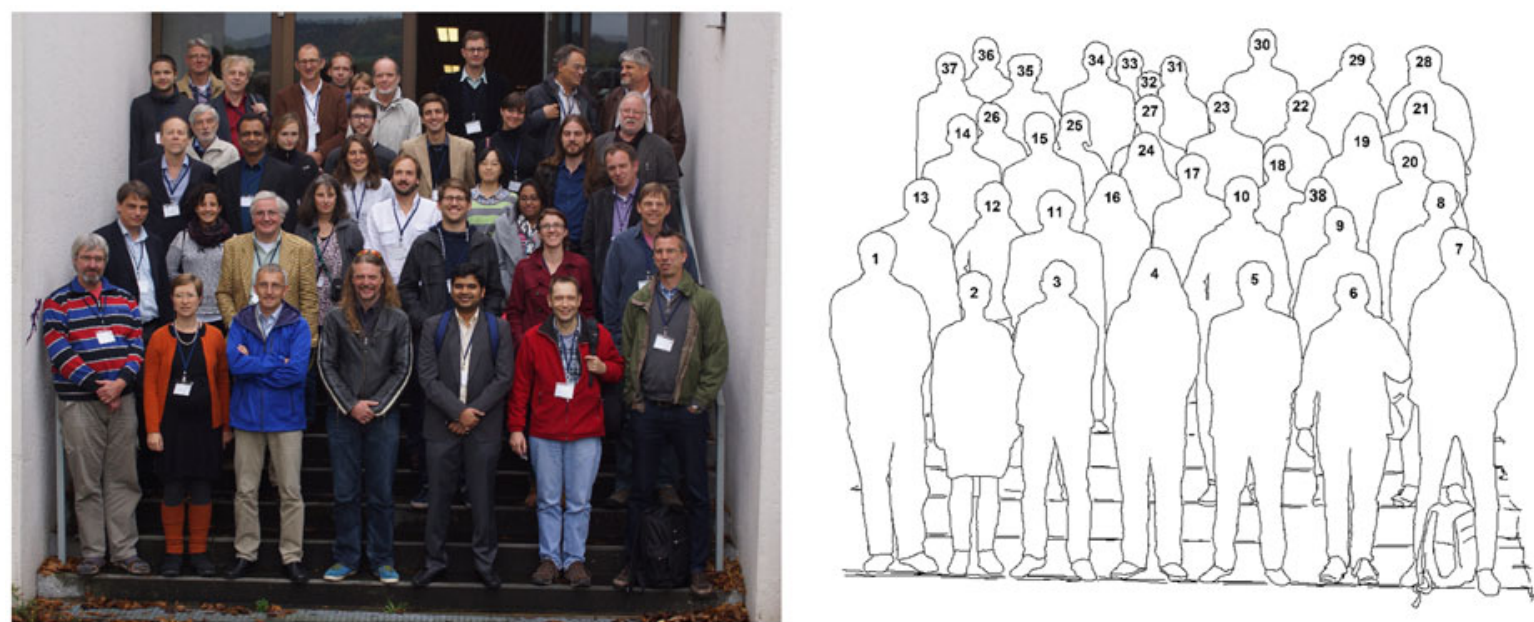

Fig. 1. Participants of the international symposium "Dating the Origin of Life: Present Day Molecules and First Fossil Record" (held in 2014 in Göttingen). 1: Wilfried Kramer, 2: Elizabeth D. Swanner, 3: Andreas Kappler, 4: Andrew Steele, 5: Chaitanya Giri, 6: Michael Hoppert, 7: Martin Blumenberg, 8: Tom McCollom, 9: Aude Picard, 10: Maximilian Halama, 11: Hans-Joachim Fritz, 12: Blanca Rincón Thomás, 13: Ulf Diederichsen, 14: Steven Benner, 15: Sudhir Kumar, 16: Dorothea Hause-Reitner, 17: Christian Hallmann, 18: Cui Luo, 19: Stefan Peters, 20: Andreas Pack, 21: Joachim Reitner, 22: Bettina Schirrmeister, 23: Jan-Peter Duda, 24: Anna Kral, 25: Natalie Bleile, 26: Fritz Eckstein, 27: Patrick Kunath, 28: Raul Schrott, 29: Manolo Gouy, 30: Walter Goetz, 31: Dietmar Porschke, 32: Nadine Schäfer, 33: Alexander Gehler, 34: Martin Van Kranendonk, 35: Blair Hedges, 36: Volker Thiel, 37: Niels Höche, 38: Sukanya Sengupta.

record and biogeochemical evidence. This is crucial for a better understanding of how our planet became an oxygen-rich place.

\section{Recent analogues for past environments}

Precambrian banded iron formations (BIFs) record one of the most fundamental transitions in Earth's history, the Great Oxidation Event (GOE) (Holland 2006; Farquhar et al. 2011; Posth et al. 2011). Koeksoy et al. (this issue) provide an overview of modern, ferruginous lakes that have been used as analogue BIF environments. These modern stratified lakes can serve as models for Precambrian ocean conditions, and so help to understand the impact of (bio-) geochemical processes on the formation of BIFs better.

Manganese-rich carbonate minerals are potential biosignatures as their formation is commonly linked to microbial processes (Okita et al. 1988; Kashefi \& Lovley 2000; Spiro et al. 2010). Rincón Tomás et al. (this issue) summarize the cycling of manganese in the presence and absence of atmospheric oxygen and discuss implications on the biogenic deposition of manganese-rich carbonates in early Archean settings. This paves way to a new type of biosignature, extending the toolkit for the detection of life on the early Earth.

\section{Understanding organic matter in the extraterrestrial realm}

Complex organic material on the surfaces of Centaurs and trans-Neptunian objects (TNOs) causes near-infrared (NIR) reflectance and, possibly, a low geometric albedo. Giri et al. (this issue) analyzed the chemical structure and composition of 'Titan tholins', showing that highly 'carbonized' complex organic material (i.e. polycyclic aromatic hydrocarbons, nanoscopic soot aggregates and cauliflower-like graphite) could contribute to the NIR reflectance and to the low geometric albedos.

Mars has been focus for the search for extraterrestrial life (e.g. Levin 1997; Westall et al. 2000, 2015; Ehrenfreund et al. 2011), and various research missions are scheduled for the future. Goetz et al. (this issue) describe strategies for the analysis of possible organic materials on Mars. Right in time for the planned launch of ESA's ExoMars mission in 2018, they discuss the value and role of ExoMars rover 
including the Mars Organic Molecule Analyzer (MOMA), a key-instrument for the identification of organic materials on the surface and subsurface of Mars.

\section{Acknowledgements}

We would like to thank the editorial team of the International Journal of Astrobiology for their efforts and constant support. All reviewers are thanked for their comments on the manuscripts. We further acknowledge the Deutsche Forschungsgemeinschaft (grants RE 665/39-1 and DU1450/3-1, DFG Priority Program 1833 "Building a habitable Earth"), the Courant Research Centre of the University of Göttingen (DFG, German Excellence Program), and the Göttingen Academy of Sciences \& Humanities (GASH) for financial and logistic support.

\section{References}

Blankenship, R.E. (2010). Early evolution of photosynthesis. Future Perspect. Plant Biol. 154, 434-438.

Blankenship, R.E. \& Hartman, H. (1998). The origin and evolution of oxygenic photosynthesis. Trends Biochem. Sci. 23(3), 94-97.

Brocks, J.J. \& Summons, R.E. (2003). 8.03 Sedimentary hydrocarbons, biomarkers for early life. In Biogeochemistry 8, ed. Schlesinger, W.H., pp. 63-115. Elsevier, Amsterdam.

Dick, S.J. \& Strick, J.E. (2004). The living universe: NASA and the development of astrobiology. Rutgers University Press, New Brunswick.

Eglinton, G. \& Calvin, M. (1967). Chemical fossils. Sci. Am. 216, 32-43.

Ehrenfreund, P. et al. (2011). Astrobiology and habitability studies in preparation for future Mars missions: trends from investigating minerals, organics and biota. Int. J. Astrobiol. 10(3), 239-253.

Farmer, J.D. (2011). Astrobiology. In Encyclopedia of Geobiology, ed. Reitner, J. \& Thiel, V., pp. 73-79. Springer, Dordrecht.

Farquhar, J., Zerkle, A.L. \& Bekker, A. (2011). Geological constraints on the origin of oxygenic photosynthesis. Photosynthesis Res. $107,11-36$.

Giri, C., McKay, C.P., Goesmann, F., Schäfer, N., Li, X., Steininger, H., Brinckerhoff, W.B., Gautier, T., Reitner, J. \& Meierhenrich, U.J. (this issue). Carbonization in Titan Tholins: implications for low albedo on surfaces of Centaurs and trans-Neptunian objects. Int. J. Astrob. 15(3), 231-238.

Goetz, W., Brinckerhoff, W.B., Arevalo Jr., R., Freissinet, C., Getty, S., Glavin, D.P., Siljeström, S., Buch, A., Stalport, F., Grubisic, A., Li, X., Pinnick, V., Danell, R., van Ameron, F.H.W., Goesmann, F., Steininger, H., Grand, N., Raulin, F., Szopa, C., Meierhenrich, U., Brucato, J.R. $\&$ the MOMA Science Team (this issue). MOMA: The challenge to search for organics and biosignatures on Mars. Int. J. Astrob. 15(3), 239-250.

Hoefs, J. (2015). Stable Isotope Geochemistry. Springer, Berlin.

Holland, H.D. (2006). The oxygenation of the atmosphere and oceans. Philos. Trans. R. Soc. B: Biol. Sci. 361, 903-915.

Kashefi, K. \& Lovley, D.R. (2000). Reduction of Fe(III), Mn(IV) and toxic metals at $100{ }^{\circ} \mathrm{C}$ by Pyrobaculum islandicum. Appl. Environ. Microbiol. 66, 1050-1056.

Knoll, A.H., Canfield, D.E. \& Konhauser, K.O. (2012). What is Geobiology? In Fundamentals of Geobiology, ed. Knoll, A.H., Canfield, D.E., Konhauser, K.O., pp. 1-4. Blackwell Publishing, Chichester, UK.

Koeksoy, E., Halama, M., Konhauser, K.O. \& Kappler, A. (this issue). Using modern ferruginous habitats to interpret Precambrian banded iron formation deposition. Int. J. Astrob. 15(3), 205-217.

Levin, G.V. (1997). The Viking labelled-release experiment and life on Mars. Proc. SPIE 3111, 30-41.

Lyons, T.W., Reinhard, C.T. \& Planavsky, N.J. (2014). The rise of oxygen in Earth's early ocean and atmosphere. Nature, 506, 307-15.

Mißbach, H., Duda, J.-P., Lünsdorf, N.K., Schmidt, B.C. \& Thiel, V. (this issue). Testing the preservation of biomarkers during experimental maturation of an immature kerogen. Int. J. Astrob. 15(3), 165-175.

Montinaro, A. \& Strauss, H. (this issue). Sulphur tales from the early Archean world. Int. J. Astrob. 15(3), 177-185.

Okita, P.M., Maynard, J.B., Spikers, E.C. \& Force, E.R. (1988). Isotopic evidence for organic matter oxidation by manganese reduction in the formation of stratiform manganese carbonate ore. Geochimica et Cosmochimica Acta 52(11), 2479-2685.

Posth, N.R., Konhauser, K.O. \& Kappler, A. (2011). Banded iron formations. In Encyclopedia of Geobiology, ed. Reitner, J. \& Thiel, V., pp. 92-102. Springer, Dordrecht.

Reitner, J. \& Thiel, V. (2011). Preface. In Encyclopedia of Geobiology, ed. Reitner, J. \& Thiel, V., pp. 27-28. Springer, Dordrecht.

Reitner, J., Duda, J.P., Fritz, H.J. eds (2014). Dating the Origin of Life: Present-Day Molecules and First Fossil Record Symposium October, 16-18, 2014. Gaia Inform 7, 1-28.

Rincón Tomás, B., Khonsari, B., Mühlen, D., Wickbold, C., Schäfer, N., Hause-Reitner, D., Hoppert, M. \& Reitner, J. (this issue). Manganese carbonates as possible biogenic relics in Archaean settings. Int. J. Astrob. 15(3), 219-229.

Schirrmeister, B.E., Sanchez-Baracaldo, P. \& Wacey, D. (this issue). Cyanobacterial evolution during the Precambrian. Int. J. Astrob. 15(3), 187-204. Spiro, T.G., Bargar, J.R., Sposito, G. \& Tebo, B.M. (2010). Bacteriogenic manganese oxides. Accounts Chem. Res. 43(1), 2-9.

Strauss, H. (1997). The isotopic composition of sedimentary sulfur through time. Palaeogeogr. Palaeoclimatol. Palaeoecol. 132, 97-118.

Treibs, A. (1934a). Chlorophyll- und Häminderivate in bituminösen Gesteinen, Erdölen, Erdwachsen und Asphalten. Ein Beitrag zur Entstehung des Erdöls. Justus Liebigs Analen der Chemie 510(1), 42-62.

Treibs, A. (1934b). Über das Vorkommen von Chlorophyllderivaten in einem Ölschiefer aus der oberen Trias. Justus Liebigs Annalen der Chemie 509(1), 103-114.

Treibs, A. (1936). Chlorophyll- und Häminderivate in organischen Mineralstoffen. Angewandte Chemie 49, 682-686.

Westall, F. et al. (2000). An ESA study for the search for life on Mars. Planet. Space Sci. 48, 181-202.

Westall, F. et al. (2015). Biosignatures on mars: what, where, and how? implications for the search for martian life. Astrobiology 15(11), 998-1029. 